\title{
ZnCdS Thin Film Chalcogenide by Chemical Bath Deposition Method
}

\author{
S. Kumarl, K.P. Tiwary ${ }^{2 *}$ \\ ${ }^{1}$ Department of Physics, Chaibasa Engineering College, Kelende, Jhinkpani, Jharkhand, India \\ ${ }^{2}$ Department of Physics, Birla Institute of Technology Mesra, Patna Campus, Patna, Bihar, India
}

\begin{abstract}
Chalcogenide ZnCdS thin films preparation by chemical bath deposition method is currently considerable interest because it is relatively inexpensive, simple and large area deposition technique. Different substrates are used since these are low temperature process which avoids oxidation and corrosion behavior of substrate. Photoelectrochemical solar cells, photoconductors, detectors, sensors, etc. are some of the applications of chalcogenide ZnCdS thin films. The effect of zinc content on structural, morphological and optical properties have been reviewed. Further, the changes occurred after annealing of the film at different temperatures and different time have also been incorporated and discussed in this article. In the present review, we have described in detail chemical bath deposition method for chalcogenide ZnCdS thin films. The method is capable of yielding good quality thin films. Their preparative parameters, structural, morphological and optical properties have been discussed in this review article.
\end{abstract}

Keywords: Metal chalcogenide, semiconductors, thin film, chemical bath deposition, solar cells

*Author for Correspondence E-mail: kptiwary@bitmesra.ac.in

\section{INTRODUCTION}

During the recent decades, electronics is more central to our lives. Semiconducting materials are the building blocks of the entire electronics that affected many aspects of the technological society. Semiconductors are helpful for our everyday life and can be used by our society. John Koenigsberger classified solid materials into metals, insulator as well as conductor and J. Weiss introduced the word 'Semiconductor' in 1910 [1]. A substance which have crystalline structure and at room temperature it consists of few free electrons is referred to as semiconductors. In early generation, semiconductors are the heart of modern electronics including transistors, solar cells, light-emitting diodes, digital and analog integrated circuits, chips/microchip, computers, etc.

The growing importance of semiconductor devices is leading to challenging in the fabrication to produce cheaper and more reliable devices. Any imperfection can change the behavior of semiconducting materials. The development of cubic or hexagonal phase depends on many features including the deposition techniques [2]. John Barden expressed the behavior of semiconductor whose properties change dramatically based on the tiny amounts of impurities [3]. Semiconductor material is one whose electrical properties lie between an insulator and conductors. The resistivity of semiconductors is less than an insulator but greater than conductor and it have bandgap from $1-4 \mathrm{eV}$ but it can go above $5 \mathrm{eV}$. The process of adding impurities to a semiconductor is known as doping. The effect of impurities on structural and optical properties of compound semiconductors are discussed [4-6]. Semiconductors are used in many devices for amplification, switching and energy conversion. Si and Ge are commonly used semiconductors but there are various semiconducting materials used for number of devices. From the past decades, the fabrication of nanocrystalline material is interested due to their unique physical and chemical properties. Among these, high surface-to-volume ratio is considerable and could lead to new atomic arrangements that affect the optical properties of nanomaterials [7]. The material which have 
one and two dimensions are in scale is referred to as 'quantum well' and 'quantum wire'.

The size reduction of semiconductor in which all the three dimension in low range of nanometer is called 'quantum dots'. Nanocrystalline materials can be classified into three categories:

1. Lamellar structures

2. Filamentary structure

3. Equiaxed structures

Nanocrystalline semiconductors exhibit the properties which lie in between bulk crystals and molecules [8]. Their electrical and optical properties are associated with quantum confinement of charge carriers leading to the blue shift of the bandgap with the shrinkage of their size [9]. When the dimension of the semiconductor quantum dots reduced close to the characteristic length referred to as exciton Bohr diameter, these characteristic lengths are usually in the range of few nanometers. There will be large change in their properties, this effect changes the surface-to-volume ratio and shifts electronic energy levels towards higher energy leading to an increase in the bandgap [10]. Nanocrystalline material properties are shape dependent, tenability in optical, electronic and catalytic properties [11-13].

Nowadays, fabrication of nanocrystalline thin film in basic research is considered as the backbone of solid state technology because of its applications in the field of photovoltaic cells, electronic components, photoconductors, sensors, optical filters, solar cells, etc. [14]. In modern era of technology, thin film have been interested for developing high efficiency solar cells and electric power with conventional source without emission of "greenhouse gases". Thin films are classified into two parts:

1. The layer and substrate where the films are deposited on it.

2. It can be composed of different layer such as thin film solar cells, electrochromic cells, etc.

According to International Energy Agency, electricity is dependent on coal, gas and oil for co-operation and development. Sun sends a mixture of heat and light in the form of energy on earth surface and both are essential for living things. Energy crisis can be minimized by using solar cells. Solar energy as one of the non-conventional source of energy and regenerated energy is abundant as well as pollution free. In 1839, E. Becquerel invented solar cell and defined that it is a device that captured sunlight and converted into electricity. Thin film solar cells can be developed because it decreases the cost of solar energy reaches to the grid parity level. Now a days, researches are progressed on thin film solar cells, CdTe solar cells and a-Si solar cells. For laboratory scale, CIGS based thin film indicates the highest efficiency among the various thin film technologies having record value of $22.6 \%$ and CdTe having $22.1 \%$. Large number of elements and compounds have semiconducting properties including some pure elements such as silicon and germanium which are used because their outermost shell have 4 valence electrons gives the ability to gain and lose electron at same time. The synthesis of some II-VI compounds nanoparticles and their optical characterization have been studied [15-18].

Over the past 25 years, metal chalcogenides (sulphides, selenides and tellurides) has been studied in the form of thin film due to their applications in photoconductive cells, photovoltaic cells and in variety of optoelectronic devices. In recent years, the compound of chalcogenide family is more interested towards thin film because it has high efficiency and is used as an energy source for the production of solar cells. The compounds of chalcopyrite families had divides into: Binary (group II-VI, III-V and IV-IV), Ternary and Quaternary compounds. A detailed classification of various types of semiconducting materials is given below in Table 1 .

Table 1: Classification of different types of semiconducting materials.

\begin{tabular}{|l|l|l|}
\hline Compounds & \multicolumn{1}{|c|}{$\begin{array}{c}\text { Types of } \\
\text { semiconductor }\end{array}$} & \multicolumn{1}{|c|}{ Examples } \\
\hline Binary & II-VI compound & $\begin{array}{l}\mathrm{ZnS}, \mathrm{ZnSe}, \mathrm{ZnTe}, \\
\mathrm{CdS}, \mathrm{CdSe}, \text { etc. }\end{array}$ \\
\hline & III-V compound & $\begin{array}{l}\mathrm{AlAs}, \mathrm{GaN}, \mathrm{GaAs}, \\
\text { InP, InAs, InSb etc. }\end{array}$ \\
\hline & IV-IV compound & $\mathrm{SiC}, \mathrm{SiGe}$, etc. \\
\hline Ternary & & $\begin{array}{l}\mathrm{GaAsP}, \mathrm{HgCdTe}, \\
\mathrm{AlGaAs}, \text { etc. }\end{array}$ \\
\hline Quaternary & & InGaAsP \\
\hline
\end{tabular}


Binary compounds of group IIB and VIA elements, commonly known as II-VI compound semiconductors exhibit larger degrees of ionic bonding than III-V compound semiconductor. Group II-VI semiconducting material of "Cadmium" based chalcogenide family have more attenuation by research community due to their unique properties and potential applications in the field of electrical, optoelectronic devices, light emitting, etc. Cadmium sulphide $(\mathrm{CdS})$ is the member of group II-VI compound. Semiconductor materials with applications in several heterojunction photovoltaic systems includes cadmium telluride (CdTe), copper indium diselenide/sulphide and copper indium gallium diselenide/sulphide (CIGS) solar cells [19]. Researchers have great attenuation on CdS thin films due to its optoelectronic properties [20]. Processing of some III-V and II-VI binary compound semiconductors for technological applications have been studied [21-23]. The optical band-gap of $\mathrm{CdS}$ nanoparticles synthesized by $\mathrm{mw}$ assisted method is found to be increased as compared to bulk [24, 25].

Addition of impurities into binary semiconducting material causes dramatic change in their increasing properties. Ternary II-VI semiconducting materials have drawn more attention than the binary II-VI compound due to their physical properties which can be controlled by their constituent mole-fraction, particle size together with morphology. A lot of focus has been given to the doping of $\mathrm{CdS}$ nanostructures with the elements such as indium $\left(\mathrm{In}^{3+}\right)$, aluminium $\left(\mathrm{Al}^{3+}\right)$, gallium $\left(\mathrm{Ga}^{3+}\right)$, boron $\left(\mathrm{B}^{2+}\right)$, manganese $\left(\mathrm{Mn}^{2+}\right)$, Iron $\left(\mathrm{Fe}^{2+}\right)$, zinc $\left(\mathrm{Zn}^{2+}\right)$, etc. that changes its optical, electrical and magnetic properties. Among these, zinc $\left(\mathrm{Zn}^{2+}\right)$ is an important transition metal element having an ionic radius $(0.074$ $\mathrm{nm})$ which is smaller than $\mathrm{Cd}^{2+}(0.097 \mathrm{~nm})$. Therefore, $\left(\mathrm{Zn}^{2+}\right)$ can easily be incorporated into $\mathrm{CdS}$ crystal lattice replaced $\mathrm{Cd}^{2+}$ ions which improves its properties. Addition of $\mathrm{Zn}$ into $\mathrm{CdS}$ leads to an increase in the energy bandgap from $2.4 \mathrm{eV}$ to $3.5 \mathrm{eV}$. The replacement of $\mathrm{CdS}$ with the higher bandgap $\mathrm{ZnCdS}$ led to a decrease in window absorption losses and result in an increase in the short- circuit current density in solar cell [26-31]. The narrow bandgap partially blocks the transmission of high energy photon to the absorber layer below and decrease the power conversion efficiency. When $\mathrm{CdS}$ is replaced by $\mathrm{Zn}_{\mathrm{x}} \mathrm{Cd}_{1-\mathrm{x}} \mathrm{S}$, the wider bandgap leads to higher quantum efficiency in blue region of spectrum. Addition of $\mathrm{Zn}$ to $\mathrm{CdS}$ buffer layer material decreases the lattice constant with a lattice match to CIGS absorber to produce a more favorable conduction band alignment. It has been observed by adding $\mathrm{Zn}$ enhances both the open circuit voltage and short circuit current density of the device to yield a higher conversion efficiency of CIGS solar cells [32, 33]. $\mathrm{ZnCdS}$ is also useful for the fabrication of p-n junction without lattice mismatch in devices on quaternary materials like $\mathrm{CuIn}_{\mathrm{x}} \mathrm{Ga}_{1-}$ ${ }_{x} \mathrm{Se}_{2}$ or $\mathrm{CuIn}\left(\mathrm{S}_{\mathrm{x}} \mathrm{Se}_{1-\mathrm{x}}\right)_{2}$. The growth parameters of the $\mathrm{ZnCdS}$ films can be tuned by varying the concentration of $\mathrm{Zn}$. Different $\mathrm{Zn}$ contents regulates the growth rate of $\mathrm{CdS}$ and is the important factor for influence the properties of the film.

There are a number of physical and chemical ways for preparing thin films and have been summarized below as shown in Table 2 .

Table 2: Methods of thin film deposition.

\begin{tabular}{|c|c|}
\hline Physical deposition & Chemical deposition \\
\hline $\begin{aligned} \text { 1. Evaporation Techniques } \\
\text { a. Vacuum thermal } \\
\text { evaporation } \\
\text { b. Electron beam } \\
\text { evaporation } \\
\text { c. Laser beam } \\
\text { evaporation } \\
\text { d. Arc evaporation } \\
\text { e. Molecular beam } \\
\text { epitaxy } \\
\text { f. Ion plating } \\
\text { evaporation }\end{aligned}$ & $\begin{array}{l}\text { 1. Chemical vapour } \\
\text { deposition } \\
\text { a. Low pressure (LPCVD) } \\
\text { b.Plasma enhanced } \\
\text { (PECVD) } \\
\text { c. Atomic layer deposition } \\
\text { (ALD) }\end{array}$ \\
\hline & 2.Sol-gel technique \\
\hline & 3.Chemical bath deposition \\
\hline & 4.Spray pyrolysis technique \\
\hline & $\begin{array}{l}\text { 5.Plating } \\
\text { a.Electroplating technique } \\
\text { b.Electroless technique }\end{array}$ \\
\hline
\end{tabular}

Among these techniques, chemical bath deposition (CBD) is the oldest method to deposit the films on a substrate and is also known as solution growth technique or controlled precipitations. CBD method is simple, 
low cost, versatile deposition over large area, does not require sophisticated instrument like vacuum system, other expensive equipment, required chemical are commonly available, working at lower temperature and capable of yielding good quality thin films. In this method, the precursor solution of metal ions must be complexed by ligands and complex solution is obtained with ammonia solution, citric acid, etc. When the complexation completed, the addition of anions come from the source of sulphur anions to deposit the chalcogenides.

\section{EXPERIMENTAL DETAILS Chalcogenide ZnCdS Thin Films by CBD Method}

In CBD method, substrates and solution are stationary and solution is stirred using magnetic stirrer. Aqueous or nonaqueous baths with constant stirring are used to heat the chemical bath to desired temperature under continuous stirring. Substrates are inserted vertical position inside the solution and left the desired film thickness is obtained. Depending upon deposition conditions such as temperature, stirring rate, solution concentration, etc. the film growth can take place by ion-by-ion condensation of materials on the substrate. In the present review article, a survey of chalcogenide $\mathrm{ZnCdS}$ thin films deposited by chemical bath deposition method is discussed (Figure 1).

The following section deals with chemical bath deposition of chalcogenide $\mathrm{ZnCdS}$ thin films. The detailed preparative conditions and properties are presented in Table 3.

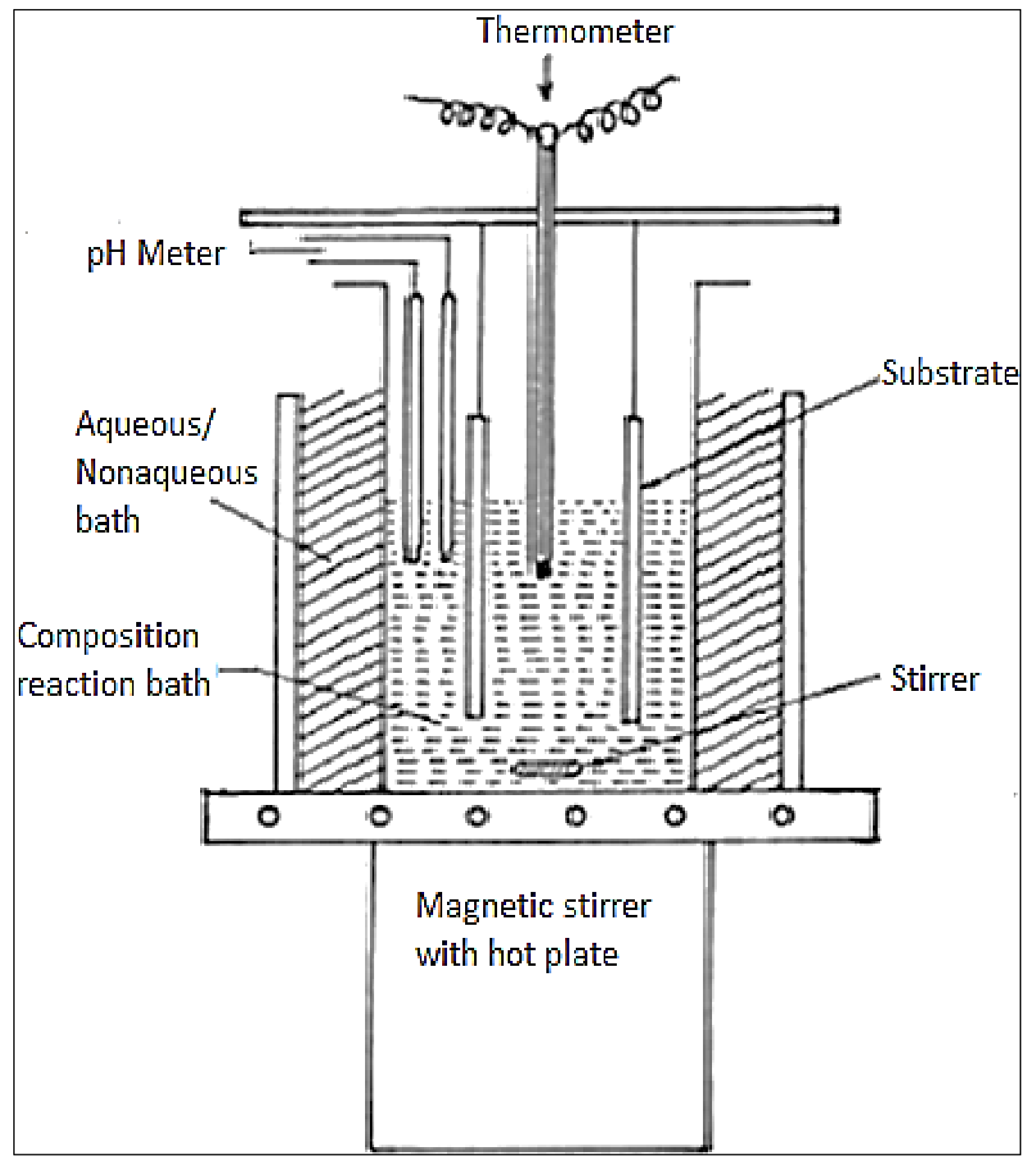

Fig. 1: Experimental setup of chemical bath deposition. 
Table 3: Preparative conditions and properties of chalcogenide $\mathrm{ZnCdS}$ thin films by CBD methods.

\begin{tabular}{|c|c|c|c|c|c|c|}
\hline S.N. & Bath composition & $\begin{array}{l}\text { Deposition } \\
\text { Temp. } \\
\left({ }^{\circ} \mathrm{C}\right) \\
\end{array}$ & $\begin{array}{l}\text { Substrates } \\
\text { used }\end{array}$ & $\begin{array}{l}\text { Deposition } \\
\text { Time }\end{array}$ & Findings & Ref. \\
\hline 1 & $\begin{array}{l}\mathrm{CdI}_{2}+\mathrm{ZnI}_{2}+\text { thiourea }+ \\
\text { ammonia }\end{array}$ & $80^{\circ}$ & Glass & $20 \min$ & $\begin{array}{l}\text { The }[\mathrm{Zn}] /[\mathrm{Cd}]+[\mathrm{Zn}] \text { ratio in }(\mathrm{Cd}, \\
\mathrm{Zn}) \mathrm{S} \text { thin films could be controlled } \\
\text { by varying the mixture ratio of } \mathrm{CdI}_{2} \\
\text { and } \mathrm{ZnI} \text { solutions. The resistivity of } \\
(\mathrm{Cd}, \mathrm{Zn}) \mathrm{S} \text { thin films are } 4- \\
8 \times 10^{7} \Omega . \mathrm{cm} \text { which depends on the } \\
{[\mathrm{Zn}] /[\mathrm{Cd}]+[\mathrm{Zn}] \text { in the solutions. The }} \\
\text { optical bandgap increased within the } \\
{[\mathrm{Zn}] /[\mathrm{Cd}]+[\mathrm{Zn}] \text { ratio, yield bowing }} \\
\text { parameter of } 0.724 \mathrm{eV} \text {. }\end{array}$ & 31 \\
\hline 2 & $\begin{array}{l}\mathrm{CdSO}_{4}+\mathrm{NH}_{4} \mathrm{OH}+ \\
\text { EDTA }+\mathrm{ZnSO}_{4}+ \\
\text { thiourea }\end{array}$ & $85^{\circ}$ & $\begin{array}{l}\text { Si (100) } \\
\text { wafers }\end{array}$ & $1-3 h$ & $\begin{array}{l}\text { From XRD spectra, the peak at } 29.2^{\circ} \\
\text { into three diffraction from (100), } \\
(002) \text { and (101) planes of hexagonal } \\
\mathrm{ZnS} \text { and (111) diffraction from cubic } \\
\mathrm{ZnS} \text { overlap representing a single } \\
\text { peak. }\end{array}$ & 32 \\
\hline 3 & $\begin{array}{l}\mathrm{CdCl}_{2}+\mathrm{NH}_{4} \mathrm{Cl}+\text { thiourea } \\
+\mathrm{ZnCl}_{2}+\mathrm{NH}_{3}\end{array}$ & $80^{\circ}-85^{\circ}$ & $\begin{array}{l}\text { Soda-lime } \\
\text { glass (SLG) }\end{array}$ & $20-90 \mathrm{~min}$ & $\begin{array}{l}\text { From XRD studies, CdZnS films } \\
\text { have hexagonal structures. Film } \\
\text { surface consists of wider grains as the } \\
\text { Zn-content increased in the solution } \\
\text { and energy bandgap at different } \mathrm{Zn} \\
\text { content }(\mathrm{Y}=0,0.3,0.5 \text { was } 2.40 \mathrm{eV}, \\
2.55 \mathrm{eV}, 2.70 \mathrm{eV}) \text {. The thickness of } \\
\text { the films is found to be } 100-200 \mathrm{~nm} \text {. }\end{array}$ & 33 \\
\hline 4 & $\begin{array}{l}(0.1 \mathrm{M}) \text { Zinc acetate }+ \\
(0.1 \mathrm{M}) \text { cadmium acetate } \\
+(0.1 \mathrm{M}) \text { thiourea }\end{array}$ & $70^{\circ}$ & Glass & $30 \mathrm{~min}$ & $\begin{array}{l}\text { Thin layer with bright yellow color } \\
\text { was formed on the film surface. From } \\
\text { XRD studies, ZnCdS films have } \\
\text { hexagonal structure with (002) } \\
\text { crystal plane. As the } \mathrm{Zn} \text { content } \\
\text { increases intensity of the film } \\
\text { increases and } \mathrm{Zn} \text {-content varied from } \\
45 \mathrm{~nm} \text { to } 72 \mathrm{~nm} \text {. ZnCdS films } \\
\text { showed a bandgap of } 3.88 \mathrm{eV} \text {. SEM } \\
\text { micrograph revealed the grains on the } \\
\text { film surface were more compact and } \\
\text { has dense structure. }\end{array}$ & 34 \\
\hline 5 & $\begin{array}{l}(0.015 \mathrm{M}) \text { cadmium } \\
\text { acetate }+(0.015 \mathrm{M}) \text { Zinc } \\
\text { acetate }+(0.05 \mathrm{M}) \\
\text { thiourea }+(0.3 \mathrm{M}) \\
\text { ammonium acetate }+ \\
(0.8 \mathrm{M}) \text { ammonia }\end{array}$ & $75^{\circ}$ & Glass & $45 \mathrm{~min}$ & $\begin{array}{l}\text { Specular yellow coloured films of } \\
\text { CdZnS are obtained. Films are } \\
\text { adhesive and sparingly reflecting. } \\
\text { The optical bandgap was } 2.8 \mathrm{eV}-3.4 \\
\text { eV. SEM micrograph indicates } \\
\text { smooth, dense, uniform grains are } \\
\text { distributed with average grains values } \\
25,11 \text { and } 13 \mathrm{~nm} \text {. }\end{array}$ & 35 \\
\hline ( & $\begin{array}{l}(0.1 \mathrm{M}) \mathrm{CdBr}_{2} .4 \mathrm{H}_{2} \mathrm{O}+ \\
(0.1 \mathrm{M}) \\
{\left[\left(\mathrm{CH}_{3} \mathrm{COO}\right)_{2} \mathrm{Zn} \cdot 2 \mathrm{H}_{2} \mathrm{O}\right]+} \\
(7.4 \mathrm{M}) \mathrm{TEA}+(1.0 \mathrm{M}) \\
\left(\mathrm{NH}_{2}\right)_{2} \mathrm{SC}\end{array}$ & $350 \mathrm{~K}$ & Glass & $24 \mathrm{~h}$ & $\begin{array}{l}\text { The optical energy bandgap is } 2.85 \\
\mathrm{eV} \text { which lies in between the values } \\
\text { of } \mathrm{CdS} \text { and } \mathrm{ZnS} \text { thin films. The } \\
\text { average optical conductivity is } \\
4.03 \times 10^{13} \mathrm{~S}^{-1} \text {. }\end{array}$ & 36 \\
\hline 7 & $\begin{array}{l}(0.06 \mathrm{M}) \mathrm{CdSO}_{4}+(0.2 \mathrm{M}) \\
\mathrm{ZnSO}_{4}+(0.6 \mathrm{M}) \text { thiourea } \\
+\mathrm{TEA}_{+} \text {ammonia }\end{array}$ & $72^{\circ}$ & Glass & $10-60 \mathrm{~min}$ & $\begin{array}{l}\text { Bright yellow orange coloured films } \\
\text { of ZnCdS are obtained. Yellowness } \\
\text { increases with increasing Zn content } \\
(\mathrm{x}=0,0.2,0.4,0.6 \text { and } 0.8) \text {. As } \\
\text { deposited films have both cubic and } \\
\text { hexagonal structure and average } \\
\text { grain size changes from } 8.75 \mathrm{~nm} \text { to } \\
3.57 \mathrm{~nm} \text { with increase in } \mathrm{Zn} \text { content } \\
\text { which is useful for gas sensing. SEM } \\
\text { micrograph reveals that as } \mathrm{Zn} \text { content } \\
\text { increases, uniform films with fibers } \\
\text { like structure appears. The bandgap is } \\
2.48 \mathrm{eV} \text { and } 3.62 \mathrm{eV} \text { for } \mathrm{Zn} \text { content } \\
\text { between } 0 \text { and } 0.8 \text { respectively. }\end{array}$ & 37 \\
\hline
\end{tabular}




\begin{tabular}{|c|c|c|c|c|c|c|}
\hline 8 & $\begin{array}{l}(0.05 \mathrm{M}) \mathrm{Cd}\left(\mathrm{OA}_{\mathrm{c}}\right)_{2} \\
+(0.05 \mathrm{M}) \mathrm{Zn}\left(\mathrm{OA}_{\mathrm{c}}\right)_{2} \\
+(12 \mathrm{M}) \mathrm{NH}_{4} \mathrm{OH}+(0.2 \mathrm{M}) \\
\mathrm{Na}_{2} \mathrm{~S}_{2} \mathrm{O}_{3}\end{array}$ & $85^{\circ}$ & Glass & $0-30 \mathrm{~min}$ & $\begin{array}{l}\text { SEM micrographs reveal that no } \\
\text { pinholes can be observed in the } \\
\text { deposited films. Annealing at } 200^{\circ} \mathrm{C} \text {, } \\
300^{\circ} \mathrm{C} \text { and } 500^{\circ} \mathrm{C} \text { film surface shows } \\
\text { the grains are not completely covered } \\
\text { the surface i.e., incomplete nucleation } \\
\text { step with irregular grain growth rate. }\end{array}$ & 38 \\
\hline 9 & $\mathrm{ZnCl}_{2}+\mathrm{CdCl}_{2}+\mathrm{NH}_{4} \mathrm{Cl}$ & $60^{\circ}-90^{\circ}$ & Glass & $1.5 \mathrm{~h}$ & $\begin{array}{l}\text { From XRD studies reveals that as the } \\
\text { bath temperature increases from } 60^{\circ} \\
\text { to } 90^{\circ} \mathrm{C} \text {, the intensity of } \mathrm{Cd}_{1-\mathrm{x}} \mathrm{Zn}_{\mathrm{x}} \mathrm{S} \\
(002) \text { becomes strong and then } \\
\text { weakens. The as deposited } \mathrm{ZnCdS} \\
\text { films are annealed at } 350^{\circ} \mathrm{C} \text { in } \mathrm{N}_{2} \\
\text { atmosphere and diffraction peak does } \\
\text { not change. The average grain size } \\
\text { changes from } 17.5 \mathrm{~nm} \text { to } 32.8 \mathrm{~nm} \text {. } \\
\mathrm{Cd} \mathrm{d}_{1-\mathrm{Z}} \mathrm{Zn} \mathrm{S} \text { thin film are used as the } \\
\text { window layer in CdTe thin film solar } \\
\text { cells. The value of activation energies } \\
\text { attributed to electron or hole } \\
\text { transitions to the conduction or } \\
\text { valence band is about } 1.67 \mathrm{eV} \text {. }\end{array}$ & 39 \\
\hline 10 & $\begin{array}{l}(0.396 \mathrm{M}) \text { Ammonium } \\
\text { nitrate }+(0.357 \mathrm{M}) \mathrm{KOH} \\
+\left(3.64 \times 10^{3}\right) \mathrm{CdCl}_{2} \\
+\left(3.64 \times 10-^{3}\right) \text { thiourea }\end{array}$ & $85^{\circ}$ & Glass & $2 \mathrm{~h}$ & $\begin{array}{l}\text { The concentration of mixture ratio is } \\
\text { varied from } 0.5 \text { to } 0.9 \text { using a relation } \\
\mathrm{x}=\left[\mathrm{Zn}^{2+}\right] /\left[\mathrm{Cd}^{2+}\right]+\left[\mathrm{Zn}^{2+}\right] \text {. Changing } \\
\text { the concentration, } \mathrm{Zn}^{2+} \text { play a key } \\
\text { role during the process of regulating } \\
\text { the growth rate and forming ternary } \\
\text { semiconductor CdZnS films. In CdS } \\
\text { thin film, atom-by-atom and the } \\
\text { hydroxide cluster mechanism play an } \\
\text { important role during the growth } \\
\text { process of thin film. However, in } \mathrm{ZnS} \\
\text { thin film, cluster-by-cluster is needed } \\
\text { for growth process. }\end{array}$ & 40 \\
\hline 11 & $\begin{array}{l}(0.2 \mathrm{M}) \mathrm{CdCl}_{2}+(0.12 \mathrm{M}) \\
\mathrm{ZnCl}_{2}+(0.4 \mathrm{M}) \text { thiourea } \\
+40 \mathrm{ml} \text { ethylene glycol }\end{array}$ & $160^{\circ}$ & Molybdenum & $15 \mathrm{~min}$ & $\begin{array}{l}\text { The concentration of both solution is } \\
\text { varied in the range from } 0.2 \text { to } 0.5 \\
\text { with the help of formula taken } \mathrm{x}= \\
{\left[\mathrm{ZnCl}_{2}\right] /\left[\mathrm{CdCl}_{2}\right]+\left[\mathrm{ZnCl}_{2}\right] \text {. XRD }} \\
\text { pattern indicates that all the as } \\
\text { deposited concentration change } \mathrm{Zn} \\
\text { doped } \mathrm{ZnCdS} \text { films exhibited }(002) \\
\text { plane at } 2 \theta=26.76^{\circ} \text { which shows the } \\
\text { hexagonal structure. As the } \mathrm{Zn} \\
\text { concentration increases grain size } \\
\text { increases. FESEM micrograph } \\
\text { reveals that grains are heavily dense } \\
\text { and unevenly distributed over the } \\
\text { film surface. EDS spectra indicates at } \\
0.2 \text { concentration no traces of Zn is } \\
\text { observed but as the concentration } \\
\text { increases spectra of Zn is observed } \\
\text { and the ratio of atomic percentage of } \\
\text { Cd and S are equal to } 1.0 \text { in all cases. } \\
\text { The energy bandgap increases from } \\
2.54 \text { eV to } 2.85 \text { eV. }\end{array}$ & 41 \\
\hline 12 & $\begin{array}{l}(0.2 \mathrm{M}) \mathrm{CdCl}_{2}+(0.12 \mathrm{M}) \\
\mathrm{ZnCl}_{2}+(0.4 \mathrm{M}) \text { thiourea } \\
+40 \mathrm{ml} \text { ethylene glycol }\end{array}$ & $160^{\circ}$ & Molybdenum & $15 \mathrm{~min}$ & $\begin{array}{l}\text { From XRD spectra, the peaks at } \\
26.76^{\circ}, 52.57^{\circ} \text { and } 56.60^{\circ} \text { are } \\
\text { observed into three diffraction with } \\
(002) \text {, (201) and (202) planes of } \\
\text { hexagonal structure. SEM } \\
\text { micrograph reveals that as ZnCdS } \\
\text { film surface is smooth, uniform, } \\
\text { pinholes, crack free, etc. The } \\
\text { bandgap was found to be } 2.45 \mathrm{eV} \text {. PL } \\
\text { emission spectra is estimated at } 382 \\
\mathrm{~nm} \text { and } 496 \mathrm{~nm} \text {. }\end{array}$ & 42 \\
\hline
\end{tabular}




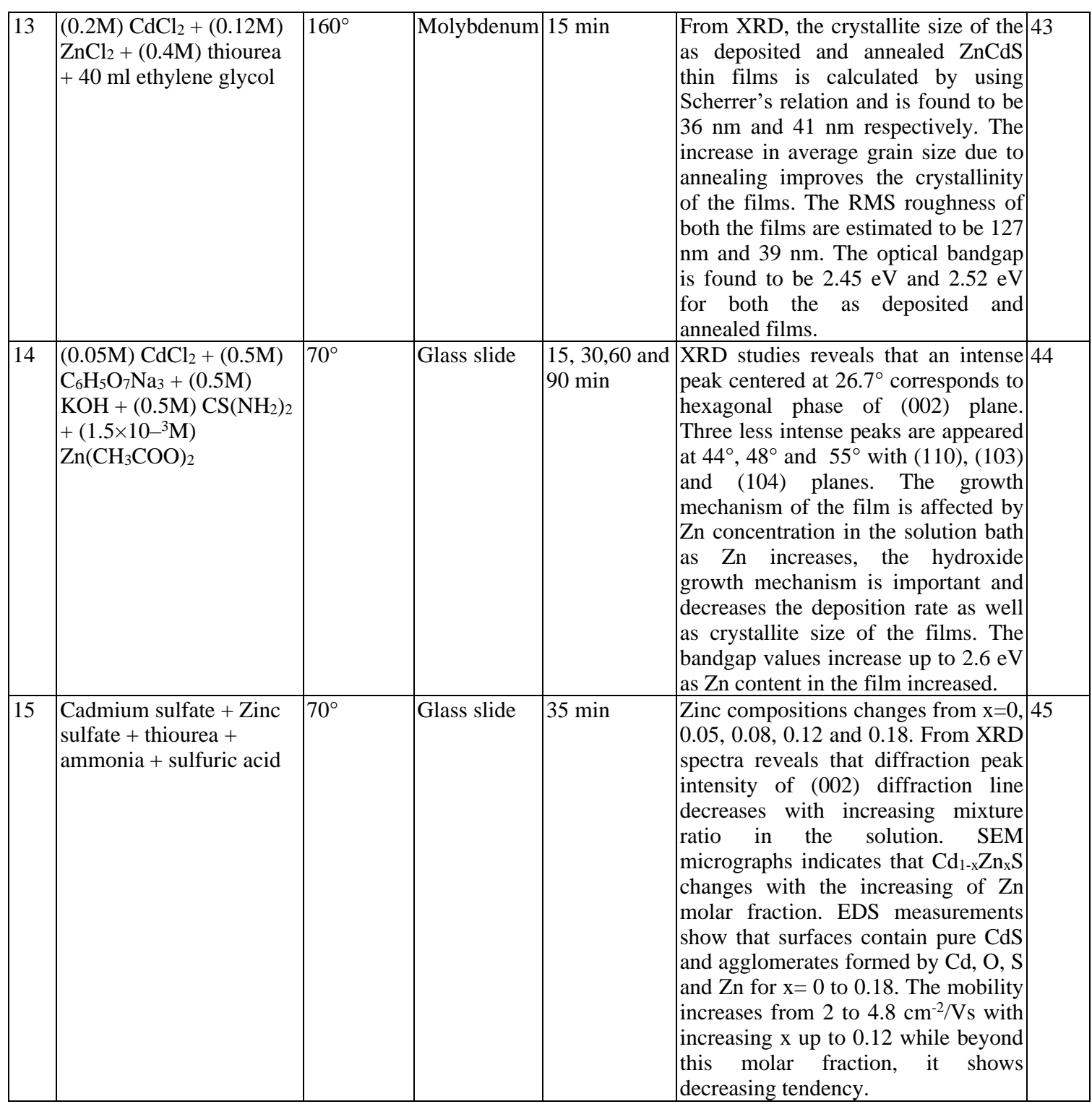

\section{CONCLUSIONS}

In the present review article, we have described the synthesis of $\mathrm{ZnCdS}$ thin films by chemical bath deposition method. This method is simple, low cost, large area deposition and capable of yielding good quality of thin films. The data presented in the tabular form indicate that the film formation could be carried out on different substrates at different conditions. The review work deals with the synthesis of $\mathrm{ZnCdS}$ thin films and their structural, morphological and optical properties have also been discussed. The devices such as solar cells, photoconductors, detectors, sensors, etc. made from $\mathrm{ZnCdS}$ thin films show the promise of the method in modern thin film technology.

\section{REFERENCES}

1. Busch G. Early history of the physics and chemistry of semiconductors-from doubts to fact in a hundred years. European Journal of Physics. 1989; 10 (4): 254-64p.

2. Joel Pantoja, Xavier Mathew. Influence of the thickness on structural, optical and electrical properties of chemical bath deposited CdS thin films. Solar Energy Materials \& Solar Cells, 76 (2003), 31322p.

3. Morris Peter Robin. A history of the world semiconductor Industry. IET 1990; ISBN0863412270, 11-25p.

4. Kumar SR, Kumar Suresh, Sharma SK, et al. Structure, composition and optical properties of nonaqueous deposited $\mathrm{ZnCdS}$ Nanocrystalline film. Materials Today: Proceedings. 2015; 2: 4563-8p.

5. Kumar R, Anjum KN, Rani S, et al. Material 
properties of $\mathrm{ZnS}$ nanoparticles incorporated soy protein isolate biopolymeric film. Plastics, Rubber and Composites. 2019; 48 (10): $1-8 \mathrm{p}$.

6. Choubey SK, Kaushik A, Tiwary KP. Influence of $\mathrm{Mg}$ on Structural and Optical Properties of $\mathrm{ZnSe}$ Nanocrystals Synthesized by Microwave Assisted Technique. Materials Today: Proceedings. 2020; 21: 1943-8p.

7. Nagarajan R, Hatton T Alan. Nanoparticles: Synthesis, stabilization, passivation, and functionalization. American Chemical Society, 2008.

8. Raji P, Sanjeeviraja C, Ramachandran K. Thermal properties of nano crystalline CdS. Cryst Res Technol. 2004; 39 (7): 617 - 22p.

9. Kotkata MF, Masoud AE, Mohamed M B, Mahmoud EA. Synthesis and structural characterization of $\mathrm{CdS}$ nanoparticles. Physica E: Low-dimensional Systems and Nanostructures. 2009; 41 (8): 1457-65p.

10. Alivisatos AP. Perspectives on the Physical Chemistry of Semiconductor Nanocrystals. J. Phys. Chem. 1996; 100 (31): 13226-39p.

11. Bakiyaraj G, Gopalakrishnan N, Dhanasekaran R. Influence of thermal annealing on the structural, optical and electrical properties of nanostructured cadmium sulphide thin films. Chalcogenide Lett. $2011 ; 8$ (7): 419-26p.

12. Satoshi Kawata (ed.). Near-field optics and surface plasmon polaritons. Berlin: springer science; 2001.

13. Bell Alexis T. The Impact of Nanoscience on Heterogeneous Catalysis. Science. 2003; 299 (5613): 1688-91p.

14. Pawar SM, Pawar BS, Kim JH, et al. Recent status of chemical bath deposited metal chalcogenide and metal oxide thin films. Current Applied physics. 2011; 11 (2): $117-$ 61p.

15. Tiwary KP, Choubey SK, Sharma K. Structural and optical properties of $\mathrm{ZnS}$ nanoparticles synthesized by microwave irradiation method. Chalcogenide letters. 2013; 10 (9): 319-23p.

16. Tiwary KP, Abbas H, Singh LSS, et al. Thermally assisted ECR etching of CdTe in $\mathrm{CCl} 2 \mathrm{~F} 2 / \mathrm{Ar}$ discharge under different gas flow ratio. Materials science in semiconductor processing. 2010; 13(2):
$102-4 \mathrm{p}$.

17. Tiwary KP, Ali F, Mishra RK, et al. Study of structural, morphological and optical properties of $\mathrm{Cu}$ and $\mathrm{Ni}$ doped $\mathrm{CdS}$ nanoparticles prepared by microwave assisted solvo thermal method. Digest Journal of Nanomaterials and Biostructures. 2019; 14(2): 305-13p.

18. Tiwary KP, Sharma Kaushlendra, Bala Neha, et al. Microwave assisted synthesis of undoped and $\mathrm{Cu}$ doped $\mathrm{CdS}$ nanoparticles and their structural, morphological and optical characterization. Materials Today: Proceedings. 2019; 18(3): 1380-7p.

19. Repins I, Glynn S, Duenow J, et al. Required Materials Properties for HighEfficiency CIGS Modules. 2009; August 26, 2009, NREL/CP-520-46235.

20. Khallaf Hani, Oladeji Isaiah O, Chai Guangyu, et al. Characterization of CdS thin films grown by chemical bath deposition using four different cadmium sources. Thin Solid Films. 2008; 516(21): 7306-12p.

21. Singh LSS, Tiwary KP, Purohit RK, et al. ECR plasma etching of GaAs in $\mathrm{CCl} 2 \mathrm{~F} 2 / \mathrm{Ar} / \mathrm{O} 2$ discharge and IR studies of the etched surface. Current Applied Physics. 2005; 5(4): 351-5p.

22. Choubey SK, Kaushik A, Tiwary KP. Structural and optical properties of pure and $\mathrm{Mg}$ doped CdSe nanoparticles synthesised by microwave assisted method. Chalcogenide Letters. 2018; 15 (3): 125$31 \mathrm{p}$.

23. Kumar R, Praveen R, Rani S, et al. ZnSe Nanoparticles Reinforced Biopolymeric Soy Protein Isolate Film. Journal of Renewable Materials. 2019; 7 (8): 749-61p.

24. Choubey SK, Tiwary KP. Digest Journal of nanomaterials and Biostructures. 2016; 11(1): 33-7p.

25. Choubey SK, Tiwary KP. International Journal of Innovative Research in Science, Engineering and Technology 2014; 3(3): 10670-4p.

26. Kim Hyeong Soo, Im Ho Bin, Moon Joo Tae. Effects of cell width on the photovoltaic properties of sintered $\mathrm{Cd}_{1-x} \mathrm{Zn}_{x} \mathrm{~S} / \mathrm{CdTe}$ solar cells. Thin Solid Films. 1992; 214 (2): 207-12p.

27. Jun YK, Im HB. Effects of Thickness and Sintering Conditions of CdS Films on the 
Photovoltaic Properties of CdS/CdTe. J. Electrochem. Soc. 1988; 135(7): 1658-61p.

28. Basol Bulent M. High-efficiency electroplated heterojunction solar cell. Journal of Applied Physics. 1984; 55(2): 601-3p.

29. Mitchell Kim W, Fahrenbruch Alan L, Bube Richard $\mathrm{H}$. Evaluation of the $\mathrm{CdS} / \mathrm{CdTe}$ heterojunction solar cell. Journal of Applied Physics. 1977; 48(10): 4365-71p.

30. Torres J, Gordillo G. Photoconductors based on $\mathrm{Zn}_{\mathrm{x}} \mathrm{Cd}_{1-\mathrm{x}} \mathrm{S}$ thin films. Thin Solid Films. 1992; 207(1-2): 231-5p.

31. Yamaguchi T, Yamamoto Y, Tanaka Tet al. $(\mathrm{Cd}, \mathrm{Zn}) \mathrm{S}$ thin films prepared by chemical bath deposition for photovoltaic devices. Thin Solid Films. 1996; 281-282: 375-8p.

32. Tosun B Selin, Pettit Chelsea, Campbell Stephen A, et al. Structure and Composition of $\mathrm{Zn}_{x} \mathrm{Cd}_{1-x} \mathrm{~S}$ Films Synthesized through Chemical Bath Deposition. ACS Appl. Mater. Interfaces. 2012; 4 (7): 3676-84p.

33. Song Jiyon, Li SS, Yoon S, et al. Growth and characterization of $\mathrm{CdZnS}$ thin film buffer layers by chemical bath deposition. 2005; IEEE: 449-52p.

34. Nagmani K, Reddy MV, Lingappa $Y$, et al. Physical properties of $\mathrm{Zn}_{x} \mathrm{Cd}_{1-\mathrm{x}} \mathrm{S}$ Nanocrystalline layers synthesized by solution Growth method. International Journal of Optoelectronic Engineering. 2012; 2(2): 1-4p.

35. Isah Kasim Uthman. Optical and morphological studies of chemical bath deposited nanocrystalline $\mathrm{Cd}_{1-\mathrm{x}} \mathrm{Zn}_{\mathrm{x}} \mathrm{S}$ Thin Films. Materials Sciences and Application. 2013; 4: 287-92p.

36. Okoli DN, Ekunobi AJ, Okeke CE. Growth and characterization of $\mathrm{ZnCdS}$ thin films by chemical bath deposition technique. Academic open internet Journal. 2006; 18: $1-12 p$.

37. Sanap VB, Pawar BH. Study of chemical bath deposited Nanocrystalline CdZnS Thin Films. Journal of Optoelectronics and Biomedical Materials. 2011; 3(2): 39-43p.

38. Jafarov MA, Nasirov EF. Nanoscale Stuctures based on the $\mathrm{Zn}_{1-\mathrm{x}} \mathrm{Cd}_{\mathrm{x}} \mathrm{S}$.
Nanosystems: Physics, Chemistry, Mathematics. 2013; 4(5): 680-9p.

39. Tian Caijuan, Gao Jingjing, Li Wei, et al. $\mathrm{Cd}_{1-\mathrm{x}} \mathrm{Zn}_{\mathrm{x}} \mathrm{S}$ Thin Films with low $\mathrm{Zn}$ content prepared by Chemical bath deposition. International Journal of Photoenergy. 2012; Article ID 549382: 1-5p.

40. Jia Guozhi, Wang Na, Gong Lei, et al. Optical properties and forming mechanism of CdZnS Thin Film grown by chemical bath deposition. Chalcogenide Letters. 2010; 7(5): 377-83p.

41. Kumar S, Rajpal S, Sharma SK, et al. Effect of $\mathrm{Zn}$ concentration on the Structural, morphological and optical properties of Ternary ZnCdS Nanocrystalline Thin Films. Digest Journal of Nanomaterials and Biostructures. 2017; 12(2): 339-47p.

42. Kumar SR, Kumar Suresh, Sharma SK, et al. Structure, Composition and Optical properties of Nonaqueous Deposited $\mathrm{ZnCdS}$ Nanocrystalline Film. Materials Today: Proceedings. 2015; 2(9): 4563-68p.

43. Kumar S, Rajpal S, Sharma SK, et al. Effect of annealing on the Surface and Optical properties of $\mathrm{ZnCdS}$ Nanocrystalline Thin Films. Chalcogenide Letters. 2017; 14(1): 17-23p.

44. Rodriguez CA, Paz MGS, Saavedra R, et al. Comprehensive Study of Growth Mechanism and Properties of Low $\mathrm{Zn}$ Content $\mathrm{Cd}_{1-\mathrm{x}} \mathrm{Zn}_{\mathrm{x}} \mathrm{S}$ Thin Films by Chemical Bath. Materials Research. 2016; 19(6): 1335-43p.

45. Khefacha Zoubeida, Benzarti Zohra, Mnari Mohamed, et al. Electrical and Optical properties of $\mathrm{Cd}_{1-\mathrm{x}} \mathrm{Zn}_{\mathrm{x}} \mathrm{S}(0 \leq \mathrm{x} \leq 0.18)$ grown by chemical Bath deposition. Journal of crystal growth. 2004; 260 (3-4): 400-9p.

\section{Cite this Article}

S. Kumar, K.P. Tiwary. ZnCdS Thin Film Chalcogenide by Chemical Bath Deposition Method. Nano Trends: A Journal of Nanotechnology and Its Applications. 2020; 22(1): 19-27p. 